\title{
WISDOM AND JUSTICE FROM A TRADITIONAL, ARTISANAL TOWARDS AN APPLIED SCI- ENTIFIC JUSTICE
}

\begin{abstract}
Wisdom in its different forms is strongly related to the harmonic use of the different types of intelligence. Wisdom we can observe even on the micro-level of the organism. On the community-macro level the need and the use of wisdom is more clearly present. Nevertheless the wisdom on the micro level is a very interesting heuristic tool too as a metaphor for better understanding the function, use and challenges of wisdom at the community level. Traditionally Justice is an important domain of application of wisdom. Today this is even more true than ever. The implications for surpassing the artisanal in favour of an Applied Scientific Justice are here really challenging.
\end{abstract}

Keywords: law, wisdom, intelligence, justice, pedagogy, metaphor, enzymes, applied scientific justice, justice-audit, macro auto-immunity, proteolytic actors, dyssocials.

\section{Introduction}

That law and in particular justice requires a great deal of wisdom is even legendary. We think of the biblical Solomon and his wisdom in administering justice. However, it is important today that we can make this so vital "wisdom" scientifically more concrete and underpinned. This means that we can make the theme of wisdom in the jurisprudence and in first place in the applied jurisprudence debatable, concrete and operational.

How can this happen? How can this be addressed? We must keep in mind that when we talk about wisdom, we envision intelligence, the multidimensionality of the intelligence and finally harmony between the many forms of intelligence mutually but also harmony concerning and in the context and situation of the participants in question. In what follows we will try to clarify and concretize this.

1. The Framework for Applied Scientific Justice

1.1 The Challenges of Justice
We know there have been many innocents sentenced to death. We know many were found to be innocent after a lifetime prison. Even on a smaller scale many things are going wrong. Structurally, in justice a lot seems to be not working correctly. It is relevant to examine more closely these structural aspects to understand better why this derailment of the judicial applications happen. It is crucial to structurally dam this derailment. Therefore we need to have an eye for the fundamental function and objectives of law in general and the criminal law in particular. We can refer here to the work of Zupancic, Hobbes, Kelsen, Beccaria, Roman law, Freud, Ranulf, Rieder, Van den Wyngaert, etc.

\subsection{The Core Task of Justice}

The core task of justice concerns peaceful conflict resolution. The alternative is "the law of the jungle: Bellum omnium contra omnes or the struggle of all against all". Culture development, progress, prosperity, creativity, etc. require a peaceful conflict resolution. When we are conscious that this is the core task and the objective of justice, 
this will have some important consequences for its applications. This includes first of all "equality" of all parties. The law should therefore prohibit that one party dominates physically the other party. In criminal law, this is a delicate question. One of the parties is the community that monopolises the physical violence. The community as a party in a conflict within a democracy - this in opposition to a party in a dictatorship - has to renounce, to abstain certainly in a conflict in criminal law, that right to violence. This means that both parties are equals in the non-use of physical violence.

This is why in justice and more specifically in criminal matters the principle of Roman law is so important: "Nemo contra se prodere tenetur" or nobody can be physically compelled to testify against himself. In the opposite case, all legality disappears. ("clearly, if the purpose of law is to prevent self-help, i.e. the resort to physical prevalence as a means of winning in the conflict, then self-help within the procedure effectively subverts the whole idea": Zupancic Prof criminal law, member constitutional court, p47).

A form of violence in favour of one party happens for instance, when a judge supervising and judging a conflict resolution, takes a side and for example takes over the job of the Public Prosecution and improvises, generates and creates hypotheses, arguments (burden of proof and burden of allegation) in its stead. In such a situation, the equality between the parties disappears completely and instead of justice, injustice is generated, i.e. justice ceases to exist. To illustrate such injustice, we can refer here to a call from a public prosecutor (Attorney General), who admitted the shortcomings of the prosecutor, but was still advising the judges to be creative and to create the necessary motivations. Indeed, it is the prosecuting party, and not the judge or the accused who has the burden of proof. The burden of proof is indivisible: the prosecuting party has both positive proof of the facts, as the negative supply evidence of the justification and blame grounds for exclusion. (Van den Wyngaert C. Strafrecht 2004 deel2 p1000).

Above-mentioned form of violence is a practice that prevails especially in criminal law and undermines criminal law in its essence. The reason why innocent people are so often mistakenly condemned can be explained in the first place by this. This form of violence, especially in criminal law, is reinforced by (1) the style used in criminal law and (2) by the overrunning of dyssocials in social pyramid hierarchies. We want to discuss these two in short.

\subsection{The Style Used in Criminal Law}

Concerning the style uses in criminal law, we cite Zupancic (p $36 \S 3, \S 4$ and $\S 5$ ), who differentiates two styles: the first is the inquisitorial style and the second is the inductive pragmatic style. As to the first style, which is typical for the European continent, he states: "... The inquisitorial model in a criminal procedure is pretentious, arrogant and authoritarian. It is pretentious because just like the persecutions of the "Holy Inquisition" it explicitly starts from the premise that "human rules are manifestations of the Divine Will and that human justice can know the whole truth." It is arrogant, because it assumes that, besides possessing the actual power, it also has the moral permission to decide on grounds of what seems true and fair to it. Moreover, it is authoritarian, because on the basis of its pretension and arrogance, it has found a rationalization for power usurpation as humans over other human beings".

\subsection{Proliferation of Dyssocials in the Social Pyra- mid Hierarchies}

The Judicial Organisation itself is not only a social pyramid hierarchy, also most prosecuted are indicted by officials from social pyramid structures. Hence it is quite crucial to understand the role, function and the harmful impact of dyssocials, particularly in social pyramid hierarchies. For explanation we want to quote following description of dyssocials: 
- In all cultures, historical or contemporary, we see that in their myths much attention is paid to addressing and treating hypocrites or dyssocials. We find that back in the myths and stories of Mesopotamia, Egypt, Greece, Rome, in Indo-European, American Indians, Islamic, Hebraic, Christian cultures, etc. (cfr. F. Vandamme 2013).

- This illustrates how important it was in ancient times, as well as in the present world, to handle, to address, hypocrites or dyssocials. In other words, it is vital to find a dynamic harmony between cooperative behavior and protective, defensive behavior. Both types of behavior are vital for survival. Wisdom is largely characterized by this harmonious balance between both. Anyway, handling hypocrites / dyssocials is an ultimate challenge of and characterizing a certain level of wisdom. Why is this the case? The answer is simple. Hypocrites, also called dyssocials, are persons (sometimes groups), who simulate very good-naturedly, friendly, social behavior. This friendly social behavior is a cover for attempts to destroy other actors, groups or even cultures, their ideals, goals...

- Hypocrites pretend to promote the ideals of others, but in reality they are trying in a hidden way to make impossible these goals or even destroy their structures. They tell us they want to promote peace (e.g.), they actually do their utmost to promote war, etc. Therefore, these dyssocials or hypocrites, can technically be called "dyssocials", referring to the Greek term "dys" which means "difficult". They are indeed "difficult-social people". It is therefore vital to prevent that cooperation is exploited or abused by dyssocials or hypocrites.

\subsection{Provisional Conclusions}

- The core of law and justice and its applications consists of conflict resolution without using any form of violence.

- The major challenge is the substitution of the inquisitorial style in justice by an applied scien- tific style based on empirical research, experiments, pragmatically and hypothetical deductive approaches in view of more efficient conflict resolution in a dynamic harmonic perspective.

- In this perspective too it is functionally needed in all organizations and particularly in those with social pyramid hierarchies, such as justice, army, universities, administrations etc., to discover and recognize dyssocials in an early stage, in order to help them to conform and above all in order to protect their victims (usually the most creative and unselfishly people in these organizations) against bullying.

- Here we can and should at least conclude that the use and application of legal judicial rulings and prosecutions should be carefully and thoughtfully handled with. Anyway, it is not acceptable to "deify"(sub and consider these forensic prosecutions and decisions a priori as being the "truth." The intent of law is to search for and find peaceful solutions to conflicts. The solutions can - like all that is human - be totally wrong...Therefore, we must be careful, especially on the basis of the current perverted inquisitorial style of the criminal courts, to attribute moral, ethical, social, etc. qualifications to people and their actions.

- In the 18 th $-19^{\text {th }}$ century's anti substantive, antiauthoritarian thinking's, social liberalism, etc. have played a pioneering role in the development of a progressive constitution in which the separation of church and state came forward. In the 21st century, all progressive, democratic and forward thinking individuals and organizations should help in the elaboration and implementation of a modern applied scientific judiciary and legal system, leaning upon a hypothetical deductive method with a broad empirical inductive basis. Continuing the support of and the collaboration with a since long-outdated justice tradition that follows the inquisitorial type, must stop. 
- This development of justice in the direction of an applied hypothetical deductive scientific method is not only possible, necessary, but is even inevitable, both nationally and internationally, given the increasing complexity of peaceful conflict resolution and the doomsday scenarios that crop up when scientifically supported alternatives fail.

2. The Micro and Macro Level of Organization: Micro the Organic, Macro the Social

\subsection{The Challenges of the Micro-Organization: an Organism}

Central here is the fight against microbes and viruses. Equally important, however, is the fight against dysplasia and in particular the fight against tumors. Dysplasia refers etymologically to " $\delta \cup \varsigma^{\prime \prime}=$ wrong (bad) and "plasia": formation. This means in other words difficult, "bad" cell formation. Certain cells become "bad cell". These are targeting, causing destruction of the organism, in particular, they may give rise to the formation of tumours, with wild growth, chaos and destruction: the destruction of the organism. The process called "dysplasia" is a process in which standard cells are transformed into cells that go their own way: even go in the destruction of the organization. Thereby they disguise as ideal cells... In these battles, the key challenges are how to prevent degeneration, derailment by autoimmunity: the destruction of the organism by its own defense? How to avoid, redirect dysplasia? Which strategies to develop to this purpose?

\subsection{The Challenge of the Macro-Organization: a}

\section{Society}

On the level of society we have the same problems. We need to defense society against internal and external attacks. The social immunity system is here crucial too. The danger, however, of autoimmunity is as big. So we have to make the following remarks:

1. Fight against lawbreakers, exploiters, against dysplasia: how to avoid individuals from degenerating into hypocrites, dyssocials. This battle is inter alia organized by law, judicial system and their manpower (police, clerks...).
2. How to avoid autoimmunity of and through the legal system, with its jurisdiction, jurisprudence, administration of justice, services and employees. Autoimmunity (e.g. by dictators, inquisition, etc.) destroys the social organization, the society.

3. The legal system and the administration of justice is an important way to maintain and improve the social organization, but through autoimmunity it can also damage the social organization. Hobbes' "bellum omnium contra omnes", may occur in different way. First, by the actions of lawbreakers, individuals and groups who destroy and block the law organization. But as much it can happen through autoimmunity: the own defense that destroys the own social structure, causing itself the degeneration of its own legal system, working so blinded that it destroys the social organization and might even create a "bellum omnium contra omnes". In the fight against autoimmunity of the legal system and the administration of justice it is important to study attentively the role of dysplasia/dyssocials (hypocrites) in the organization, control, validation and evaluation of the legal system, the judiciary and their officials.

3. Intervening and Combating Attacks on the Micro- and Macro-Organization

\subsection{The Challenge}

Intervening and combating attacks and attackers on the micro as well as at the macro level can be done in many different ways. However in this defensive, we must also take into account, inter alia, the side effects and the so-called "collateral damages: or the unintended and sometimes unexpected incurred damages". These are sometimes worse than the ailment. Not only the enemy is fought, at best eliminated, but there is always the danger that many or small parts of the own organism (cfr. own society at a macro level) are temporary or permanently damaged or maimed. Even worse is that the immune system or in other words, the defense system itself is transformed, and instead of defending 
the own organism (the society at the macro level), it is attacking it. This is the so well-known but dangerous phenomenon of auto-immunity. The defense becomes in its turn oppressor that disrupts, damages, destroys partially or totally its own entire organism / society.

From this perspective, we can view the general strategies on both the macro and the micro level, with their collateral side effects and risks.

In this overview, it is really important to have an eye not only for the structural conditions and levers to dysplasia. It may be just as crucial and even more important to have an eye for the conditions and levers for EUPLASIA. By this we mean the ability to transform hypocrites, dyssocials: destructive cells (on a macro-level individuals or groups) into constructive, useful cells... The fact is that it seems to be more promising to focus on transformation, on reform of the cells (tumor cells), individuals (dyssocials) and / or groups, instead of focusing on destructing them. The risk of derailment is very high, too high.

\subsection{Contemporary Strategies at Micro Level to} Combating and Correcting Attackers (harmful bacteria, viruses, tumor cells...)

We will in the first instance concentrate our attention on the tumour cells. We can repeat approximately the same concerning the control of bacteria, viruses, whereby the same problems arise.

The steps made to combat tumors and other attackers at the micro level are evident, even though some solutions have required a lot of research, experimentation and testing. Of course we have "surgery": cutting out the tumor (1), preferably before it enters the stage of metastasis production (metastasis: dissemination of tumor cells throughout the whole organism). The following solutions were radiotherapy and chemotherapy. The first radiotherapy (2) was realized in 1896, more exactly a year after the discovery of X-rays by Roentgen (Dewaele 2015: 10). Another type of approach is chemotherapy (3). This approach is much more recent and has arisen as a result of an yperite disaster during WWII in Bari (Dewaele 2015: 11). Naturally here many variations and combinations exist. The great problem of course, are the side effects and the risk of autoimmunity. A fourth type involves the use of inhibitors (type INIB and type UMAB). INIBs are small molecules that penetrate through the membranes of the cells and block within these cells further development. "UMAB" are large molecules that act on the tumor cell from the outside and block them very selectively. A fifth way is acting on the surroundings of the tumor cells, so that metastases can be blocked. For example, we can think of shutting off the supply of nutrients and oxygen to the tumor cells, which are able to develop very efficiently new blood vessels to feed them. Here there are many interesting interventions possible.

One of the crucial problems in combating tumors is the phenomenon that tumors have a very dynamic ability to disguise themselves, whereby the immune system becomes unable to recognize the tumors that must be fought /controlled. This happens rather frequently, hence the term dysplasia (dyssocial at the level of the social organization). What is more tumours have different methods to hide, to cover themselves. Methods are being developed to inhibit, to break through this disguise. This is a major breakthrough in the fight against cancer and tumors. However, it should be recognized that these techniques and methods have as side effect that they can result in auto-immunity, in other words, that also the own non-tumour cells can be attacked. Of course, attempts can and will be made at the different approaches against tumours, always to have an eye on 1) the side-effects, 2) the risk of auto-immunity, and finally 3) the risk of resistance against the applied products and methods.

\subsection{Euplasia at the Micro Level of the Organism.}

\subsubsection{Breaking through the Disguises of the Tu-} mour Cells.

With the approach of fighting the disguises of the tumor cells, we are actually right in the chal- 
lenge of Euplasia. With dysplasia we have the phenomenon that normal cell formation leads to transformation into cells that are destructive to the harmonious development of the organism. With euplasia $($ eu $($ Greek) = good; plasia (Greek): cell formation), we have the process of transformation of bad / harmful functioning cells in the organism into good / useful functioning cells. The major problem with euplasia is the problem of resistance, when the tumour cells become immune to the transformation processes. What is worse, the tumour cells can form new disguises to achieve their destructive work in the organism yet more efficiently.

3.3.2 A next step, but for now still a wishful dream concerning tumours, is not only breaking through the disguises of the tumor cells so that they could be easily destroyed by the immune system. Even better is the alternative wherein the tumor cell could be transformed into a normally functioning cell, which could be positively engaged in the target organism. Obviously, this is also a very vital step in the macro-social approach of dysplasia and euplasia.

4. Macro Applied Scientific Approach to Justice and Law system

\subsection{The Challenge}

As in the organism, we have within society the important task and duty to create harmony that enables development, prosperity, and welfare of and in society. Fighting the forces and influences that threaten society-organization and lead to Hobbes' nightmare of "Bellum omnium contra omnes": war of all against all, or in other words the complete chaos... is here also at the center. The justice and legal system, as stated by many authors and so beautifully formulated by Zupancic is a crucial "immune system" that could and should save society. As we have already described we have in the operation of this social immune system, like in the organism (micro level), the fight against lawbreakers, the problem of dyssocials (tumor cells): dysplasia and euplasia. Also in the legal system, we have the challenges and threats of the side effects of the secondary unintended damage (collateral damage) caused by Justice and the legal system. Moreover, we have the risk of autoimmunity, viz. that the legal system, in its fight against illegality, endangers, breaks off, even destroys completely its own social organization. Finally, we also have the problem of resistance, where the lawbreakers, dyssocials adapt themselves. The attacks then persist and even intensify. These dangerous developments and menacing effects of law application are the development of autoimmunity, caused side effects, damage caused by its application and the resulting resistance through this application.

This is the context in which the applied scientific approach to justice and legal system needs to be adjusted, as an empirical, experimental (subject to very specific conditions) science, in which nonviolent conflict resolution of individuals and groups stimulating harmonious development of society is and remains the central issue.

\subsection{Strategies for tackling lawbreakers and for con-}

flict resolution in the framework of the Judiciary and Legal System development of social "Immunity".

Traditionally, we have the "surgical intervention" as a societal immunity strategy. The banishment and elimination of the lawbreaker(s), in the many forms of punishment by banishing, dispossessing and killing the "offenders". This is a fairly quite rudimentary naive approach that always has lead and still leads to autoimmunity: social, selfdestruction to a greater or lesser extent. The justice and legal system destroy and eliminate again and again the most creative and constructive elements in society. Frequently it also harms the prosperity, well-being and welfare by reason of blind, naive, emotional use of law in function of or because of short-sighted self-assertion, blind supremacy feeling or emotional gut instinct when using justice and the legal conflict resolution by the judge and the legal system. It is therefore high time to search intensively for methods and techniques favoring a 
more balanced and non-violent conflict resolution, as stated by Zupancic and so many others. In any case, the inquisition-style of justice is a typical autoimmune phenomenon in the judicial / legal system. This must be contested as fast and as thoroughly as possible.

In this process of conflict resolution the main concern should be the resolution of conflicts in which the involvement of violence (both open and hidden cfr. dyssocials) is directly or indirectly prevented. An important dimension in this conflict resolution approach, in the context of the build-up and defense of the social immunity, is that one should stop restricting oneself to a one-dimensional intelligence approach of the so-called rational intelligence. The society needs to use all the forms of intelligence to maintain social harmony. In a onedimensional, so called rational intelligence approach we have a reduction of perspectives whereby all kinds of considerations and interests can easily be hidden and used in a way that manipulates and injures the involved individuals and groups. Thence in a serious applied scientific implementation of societal immunity and conflict resolution, we must dare to employ and involve every kind of intelligence in the immunity combat and conflict resolution at all levels.

\section{The Use of Pluri-intelligence in Applied Scien- tific Judicial Conflict Resolution.}

\subsection{Introduction:}

It is evident applied scientific judicial conflict resolution requires the use of intelligence as much as possible. Of course it is important to keep in mind that intelligence always takes many different forms. Given the delicate and complex nature of conflict resolution in general, and of legal conflict resolution in particular, it is important also to be aware of the multiple forms of intelligence, which are also relevant here and should be employed maximally. In any case it would be artificial and inefficient to limit oneself, as usually happens, to rational intelligence. This rational intelligence, while important, is only to be an economic perspective on intelligence and therefore much too poor to be the driving force behind the legal conflict resolution.

Which are the other forms of intelligence that are at least equally important. We can mention here among the main types of intelligence: the caring intelligence, energetic intelligence, emotional intelligence, action intelligence, rational intelligence, storing intelligence, transcendental intelligence, integrative intelligence and sexual or love intelligence. We want to discuss some of these forms of intelligence in terms of their relevance to applied scientific judicial conflict resolution.

\subsection{The Caring Intelligence and Judicial Conflict} Resolution.

One of the crucial and most important forms of intelligence, perhaps the mother of all intelligences is the caring intelligence. One is concerned about oneself as an individual, about the kids, family, the group, the material in the environment, the community, the nation, the culture, the environment, nature... These different forms of care and corresponding intelligence must be brought into harmony mutually.

Let us apply this to judicial conflict resolution where caring intelligence is employed. "Care" is a primary, huge mainspring as well as target and motivator in judicial conflict resolution in criminal law, civil law, etc... In criminal law the care of all interested parties (in the first instance the civil party) is clear. In the second instance it concern the guardians of the law, judicial investigators, the public prosecutor. In the third instance this is true for the judges in their various grades and qualities. Finally, we have the defense. Each of these parties have in their way to do with caring intelligence.

As for the civil parties, the care is usually the basis of the conflict in the conflict resolution. If the civil parties have no advantage in the conflict and conflict resolution, or even see the conflict as a threat to their own interests, then one must be careful because some parties: judicial investigators, public prosecutors, even the judiciary, might evoke artificially or intensify the basic conflict out of per- 
sonal interest, as a dyssocial or as a leverage generating or strengthening other problems, conflicts. If the latter is the case, haven't we actually de facto to do with in-depth pseudo conflict resolution? Such a pseudo conflict resolution might become even worse when the judges: those who are to settle the conflict resolution, position themselves in the place of the civil parties and act implicitly in their name to eventually decide upon the in reality "pseudo conflict".

In the perspective of the inquisition style of judicial action in conflict resolution, it is vital to detect, to correct and sanction such pseudo-care conflicts by all meta-guardians of the care interests, be it judicial inquisitors, public prosecutors and judges themselves. One of the biggest sources of dysfunction of justice is related to this abuse of the caring tasks and caring intelligence of individuals and representatives of organizations and the arbitrariness in their interpretation, propositions and descriptions of the (whether or not pseudo) conflicts and their legal treatment. Anyway juridical conflicts in which the civil parties refuse or fail to act, are always very suspicious as to abuses of such conflicts by dyssocials, in society or in the meta-care management by judicial investigators (police in whatever form), prosecutors and even the judiciary in the manipulation of their legal conflict resolution.

\subsection{Emotional Intelligence and Judicial Conflict Resolution.}

Emotional intelligence is crucial for individuals and groups to respond as quickly as possible, as adequately as possible to changes, threats from the environment and information from that environment. Emotional intelligence reacts "viscerally" integrating total experiences of an individual, his entire background (even including know-how transferred from previous generations) to the extent that these are built into the reflexes of an individual. Emotional intelligence is therefore very far-reaching in the designation and interpretation processes and buildup of the expectations towards actors, young- er as well as older ones, as well as on other stimuli in the environment.

How important emotional intelligence is to the survival and success in the surroundings, the less reliable, however, it is to guide, to evaluate, to direct judicial conflict resolution. Indeed emotional intelligence is maximally focused on individual immediate quick action. This rapidity is based as stated already on implicit knowledge and expectations that are maximally subjective. Conflict resolution in general and law conflict resolution in particular, should be maximally objective in the sense of maximally inter-subjective. We mean that the perspectives of multiple stakeholders should be taken into account in order to give as much attention as possible to the "facts" i.e. establishments that are made from different perspectives. Emotional intelligence, especially from the perspective of the judges and equally from the perspective of the police i.e. those who are expected to make analyses and statements, in particular the official prosecutor (public prosecution) is completely unacceptable, fundamentally wrong.

As Zupancic describes, however, this emotional intelligence unfortunately is prevalent in the contemporary inquisition style of justice and consequently in the contemporary judicial conflict resolution. This also means that one must have maximal attention in the assessment of the quality in justice administration, for the recognition and making explicit of the emotional intelligence present and used by the operators of justice.

We should not only make explicit the emotional intelligence used and even hided. We should also ensure that every time after discovery of emotional intelligence used, its role in legal conflict resolution, is cleansed away. By this we do not mean that it must be concealed in the legal process, but on the contrary that after making explicit, its impact should be eliminated, cleansed away. This precisely by showing that emotional intelligence, as a disturbing factor in an objective i.e. intersubjective way in conflict resolution, has been clari- 
fied and made understood to all parties involved and as a disturbing factor be discussed, treated and removed by all parties involved in the decisions of the conflict resolution. Indeed there is nothing worse than emotional intelligence used, remaining hidden and irrationally becoming decisive in the final conflict resolution. This is not only unworthy for justice but also for humanity.

\subsection{Preservative (storing) Intelligence and Juridical Conflict Resolution.}

For all systems, whether individual or group (organizations, cultures), the preservation of the existing system is important. In conflict resolution in general, and Juridical Conflict Resolution in particular, it is crucial to keep in mind the impact of the conflict on the safeguarding of the system and the quality of the system that is remaining. It particular the staff responsible for the follow up and finalizing the conflict resolution have to keep in mind the impact on the existence, survival and the quality of life of systems and the actors involved. More especially they have to keep in mind and to have an eye on dyssocials. They are responsible that dyssocials do not use the conflict solely for the realization of aimless destruction of the quality and viability of the system (organization)and their actors involved which they engage in a judicial legal conflict. Preservative and storing intelligence in the judges and judicial actors should be very carefully developed and monitored through assessment and evaluation of court legal judicial conflict resolutions.

\subsection{Rational Intelligence Juridical Conflict Reso-} lution.

We have to consider rational intelligence at as an aesthetic factor. This is about economicity, i.e. the number of principles and steps necessary for example to resolve a conflict. The fewer principles, the less rules and steps are needed to be applied for working out a system, a challenge, a problem, how more economic, and hence more beautiful a system is. However, we must be careful not to make a fetish of this economic / aesthetic principle. Rational intelligence is just a mean, a tool, but not an end in itself. Ultimately, the impact of the legal conflict resolution is more important for maintaining, preserving sustainability, welfare, prosperity and harmony in the community and cultures where the legal conflict resolution is applied. The rationality that is the aesthetic outlook is just secondary.

\subsection{The love intelligence and Juridical conflict re- solution}

We have experienced that love intelligence, like emotional intelligence, takes a special place in the legal conflict resolution. It is first of all a given about which the actors in the legal judicial resolution follow up and resolution should be maximally conscious. This at every level and every stage: in establishing the facts, aspects, components, in analysing... in judging, in the solutions. The plaintiffs and the decision makers: the courts judges, prosecutor, the involved parties, etc. should pay attention to the processes and cycles in which the love intelligence plays a role and to the extent that they play a role. Conversely, they have to be aware of the power and the rights the actors have, to use their love and emotional intelligence. Though, it is also clear that however much they could and should empathize with the reality, forms, life cycles that are present e.g. in the love intelligence, themselves as legal conflict resolution actors and counsellors must distance themselves maximally from the emotional intelligence as well as love intelligence in guiding and controlling, directing the involved conflict resolution. This means that to the extent that they are themselves in love with an actor involved in the conflict, they have to distance themselves from any involvement in the legal conflict resolution.

\subsection{The action intelligence and judicial conflict res- olution}

The action intelligence is very crucial for every individual and social system. Hence, its impact on the actions is very important for each individual and organization, this notably in judicial conflict resolution. This has to be made sufficiently operational, both to the actors involved in the conflict resolu- 
tion, as to the corresponding meta-actors being the analysts (researchers), the public prosecutor and the judges.

\subsection{The energetic intelligence and judicial conflict resolution}

The impact of the energetic intelligence on the actions for an individual or organization has to be taken into account when one intervenes in, builds up, develops and implements a conflict resolution. Indeed energetic intelligence is very crucial for every system individually or socially. It is also needed that this approach is made sufficiently operational. This concerns the actors involved in the conflict resolution, as well as the involved meta-actors in the judicial conflict resolution being the analysts (researchers), the public prosecutors and the judges.

\subsection{The persuasive intelligence}

Convincing others and also oneself requires a very specific intelligence. For the organization, management, control and stimulation, this intelligence is very important. In law generally and in applied scientific law particularly persuasive intelligence plays a very crucial role. This is among inter alia, expressed in the jurisprudence when referring to "have the ear of the judge." But this persuasive intelligence is not limited only to the judge. It has also an important role in communication with the opponents and all other parties involved in the procedures of law in other words in the resolution of the judicial conflict

\subsection{The heuristic intelligence}

This intelligence is important in the search for data, facts that are relevant to find or solve challenges and problems including those concerning judicial conflict resolution. Heuristic intelligence can be very diverse in nature and may or may not be supported by highly advanced techniques such as statistics and search algorithms.

\subsection{Transcendental Intelligence and Juridical Con-}

\section{flict resolution.}

Transcendental intelligence is for the community very important for transcending the individual interest of an actor, having an eye for inno- vation, and the unselfish consequences of that renewal, for the individual himself, but also having an eye for the interests of the greater whole: group, community, culture, environment, nature etc... Transcendent intelligence, however important to the community, entails a whole range of dangers. It is important in the legal and judicial conflict resolution to have an eye especially concerning the risks, which the innovator, the bringer of transcendent intelligence incurs. Therefore he need to be protected by the responsible actors in the juridical conflict resolution.

Regarding the dangers to the contributor of transcendent intelligence, we need to be aware that those are dual in nature. First of all, we have the danger coming from the dyssocials, in their search for destruction of organizations, cultures. They are targeting especially those bringers of transcendent intelligence. By hitting them, they affect, they damage deeply the future of an organization, a society, a culture. Here their destruction has the greatest chance of profound, radical negative impact. That is why these innovators are always again the first victims of dyssocials. Moreover, we have that dyssocials are not only more successful in their destruction through addressing the transcendent intelligence actors. It is so that from the very nature of transcendent intelligence, these actors are more vulnerable. Why, however, are transcendent intelligence actors more vulnerable? Transcendent intelligence actors have the following characteristics:

1) They bring innovation.

2) They are more altruistic: their own interest is absent or only present at the background, or only present as a meta-value of innovation for innovation, or of innovation for a higher general welfare, prosperity.

But these are both features that are easily made suspicious or in se are suspect because they bring deviation to the existing situation, existing interests, existing habits... 
Concerning renewal, innovation we can state that these are usually following the below described cycle:

Phase 1: innovation is seen as just stupidity.

Phase 2: wonderment

Phase 3: considering/ interpreting as trivial: we have always known this: the idea is trivial, obvious.

This means that innovators may easily be attacked and excluded by the community. Thus they are a grateful targets for dyssocials. That is why they should be given extra protection in legal judicial conflict resolution.

The second reason why bearers / providers of transcendent intelligence, are so vulnerable is that we could almost say that this is because of the very nature of transcendent intelligence- they are so altruistic, i.e. they have no personal interest in the development and realization of their transcendent knowledge. However, when is established that there is no self-interest, generally one becomes suspicious and may quickly suggest, make suspicious that all kinds of machinations are trying to hide their own interests. Here dyssocials find a vast and fertile field for impeachment or machinations. Also for this reason, extra protection by the staff responsible for/ in charge of /judicial legal resolution is needed and wanted.

\subsection{The integrative intelligence in the judicial con-}

\section{flict resolution (Harmony)}

In every conflict resolution including judicial conflict resolution in particular, it is important and crucial on two levels to keep the integrative intelligence in the eye. The integrative intelligence strives to achieve a harmony between all perspectives applicable to a determinate system (an individual, an organization, a culture). This can also be done by pursuing a harmonization between the different forms of intelligence. Even so, and equally important is to pursue a harmony between the various evaluation dimensions that are applicable to a system.

At the level of judicial conflict resolution we also have that on both levels harmony could be pur- sued from the perspective of the direct actors in the conflict as well as from the perspective of metaactors of the I conflict resolution (the analysts, investigators, prosecutors, judges...) Harmony is in both perspectives really the crucial goal!!!

\section{What definitely not to do in a pluri-intelligent} approach of judicial conflict resolution

Zupancic (2014) in his work has described quite extensively the dangers of the inquisitorial style in jurisdiction that is expanding and growing very strongly in both the continental and the AngloSaxon law. We can describe concisely the inquisitorial style of justice as a jurisdiction departing from an emotional intelligence, disguised or couched in a rational intelligence. Moreover we see that this style, starting from the top level of the "Judges", through positive feedback, takes over the whole legal system from the top to the base. Eventually, we will inevitably see that because of this style in the administration of justice, the entire society is becoming by it affected deeply. As a consequence, legal certainty is disappearing, with all its consequences. This inquisitorial style of law leads therefore inevitably to chaos, i.e. to the "Bellum omnium contra omnes", what jurisdiction specifically is intended to avoid, being even precisely its fundamental mission.

Let us briefly discuss the higher descriptions of the inquisitorial style of justice. We have provisionally characterized the inquisitorial style of justice as starting from emotional intelligence. By itself, emotional intelligence is not abnormal or wrong. Usually each individual, each actor, an average individual, and thus also a judge, begins with his emotional intelligence when tackling a case. It is important to confront this with the many other forms of intelligence and subsequently to try to achieve a harmony between the different intelligences. Indeed, even though the emotional intelligence is important for introduction and situating, it is very dangerous if it is too fragmentary, too onesided, too largely determined by one's own personal and social experiences. 
When emotional intelligence happens to reach, to achieve a conclusion, a result. We have to be aware though that this has been established quite quickly, sometimes in a fraction of a second, based on all kinds of details: smell, color, clothing, view look, movements, tics... of the accused for example. This preconception might remain prominent since emotional intelligence is very difficult to change in the course of the process even when new data and information have been introduced.

The rational intelligence in the inquisitorial style of law is then generally used merely as a means of least effort (rationalization), to build an argument to support the conclusion of the emotional intelligence. This means that the accused (individual, group...), stands very little chance to go against such rational "cover" and pseudo support of an emotional intelligence conclusion. Every counter argument will thus be considered irrelevant.

Besides, in the inquisition style of justice by judges, the frequently employed strategy consists of formulating hypotheses in the form of considerations, based on some cited findings or evidence adduced by third parties in the dossier. These hypotheses are then presented as an argument or an evidence of guilt. Introducing hypotheses, precisely by the prosecutor is certainly acceptable on condition that the accused and his defense can have the opportunity to refute these, and /or introduce other explanatory hypotheses. But the introduction of new hypotheses, even in the form of considerations as a new element in the judgment as an argument or proof undermines the rights of the defense. This is totally unacceptable.

Hence, usually when the inquisitorial style of justice is used, the only way left to the defence, to achieve results is the procedural outcome: by identifying and invoking procedural errors in the hope that they will be considered relevant at a higher level. But also this procedural way out and fight against the inquisitorial style in the judiciary is highly vulnerable in the light of the positive feedback generated by the inquisitorial style. This positive feedback is one of the hazardous effects of the inquisitorial style of justice. This forms the basis of the autoimmunity consequences of this style, namely undermining the legal system and the judiciary as the motor for applied scientific approach to conflict resolution. Moreover, this inquisitorial style of justice generates and will generate and stimulate more and bigger conflicts in society at large. This leads to increasing violence and even to absolute dictatorship.

What is that positive feedback we are talking about? We know that in each system unlimited positive feedback will lead to the destruction of this system. It is vital to turn that positive feedback at some point into negative feedback. A classic example is a thermostat in a heating system. When, within such a system, it is established that the target temperature is not reached, for example $25^{\circ}$, then heat will be further generated until this temperature is reached. The heat production is then stopped: negative feedback. Suppose however, that the gauge of the temperature is defective, the system will permanently produce more and more heat until it explodes... That is why "negative feedback" is so vital, to stop the heat production at some point!!!

Now, we see that the inquisitorial style of justice within law is stimulating unlimited positive feedback both upwards as downwards. We mean the following. Emotional intelligence, or if you prefer, the gut, feeling, instinct of the judge with his rational background and cover-up, is contagious downwards to the investigating judges, the inspectors, police officers, who through the example of the court are also stimulated to work, based on their gut, feeling with selective rational and pseudo intelligent framework and elaborations. Also upwards to higher judges and courts, we see an increase and growth of the same inquisitorial style. In this perspective for instance, we saw recently in some countries how the use of illegally obtained information by the tax department, may and can lawfully be used in court. This has led to the state- 
ment of some lawyers, legal experts and jurists that slowly but surely in the end every form of violence will be approved, admitted by the court with the exception perhaps of physical violence against and on the accused.

\section{What certainly to do in a pluri-intelligence ap-} proach to conflict resolution: Judiciary audit and Law System audit: Key and motor of an applied scientific judiciary and legal system.

As with all scientific and certainly applied scientific approach, it is inevitable and crucial to work out, collect, elaborate experiences, observations, testing's, hypotheses (to provide /formulate answers) evaluate, validate etc. Inevitably mistakes, errors, etc. will be made. This is not so bad insofar as one learns from his mistakes. Therefore it is crucial that in pursuing and interpreting juridical conflict resolutions, the success and the degree of success but also the failures and even the fundamental failures are not only observed and recorded at regular times but also measured. Adjustments will have of course to be done. This may concern details. However, it may also be necessary to intervene and make changes structurally.

The essential way of approach is that periodically, every three to four years, for example, an in-depth knowledge audit or knowledge management audit is conducted for each specific court to establish and measure the results, approaches, success etc., at its different levels of operation. The existing know-how of knowledge audit and knowledge management will provide an important contribution here (see Vandamme 2012 Knowledge Management). Obviously the knowledge management audit methodology has to be adapted to the specific needs and challenges of the judiciary and legal system knowledge management, practices and challenges.

In this perspective it is quite fundamental that in the knowledge audit much attention has to be paid to the style of the judiciary. In particular attention is required concerning the detection, the slip- pages and dangers of the inquisitorial style of justice.

8. The enzymes metaphor of the Applied Scientific Judicial Conflict Resolution.

\subsection{Introduction}

As an individual: human, animal, plant is an organism, society equally forms a kind of organism. In order to better understand the society, it may be useful to look at the functioning and the optimization of the functioning of the organism of an individual e.g. of a human. We know how important enzymes are to the good functioning of a human body: We quote: "... It is believed that there are hundreds of thousands of enzymes in the body performing different functions. Without them there is no life. The life span of an organism is inversely proportional to the degree of exhaustion of the enzymatic capacity of the organism. So, the less enzymes present in the human body, the sicker the organism is and the shorter it lives."(Filip Muylle). Something analogous we may suggest for the social organism. The enzymes are here the social operators!

\subsection{The types of enzymes:}

The great mass of enzymes are commonly divided into five groups. Briefly, the following types exist:

1) Digestive enzymes,

2) The system or metabolic enzymes, These are the enzymes that mainly play a role in the regulation of energy (via liver, gallbladder, and pancreas).

3) The intra-cellular enzymes. These mainly have a restoring function within the cells,

4) The proteolytic enzymes, which mainly have a protective, defensive function,

5) The enzymes which insure production of enzymes.

It is indeed important to keep in mind that these different types of enzymes themselves, integrate/contain many of the same enzymes. We also need to keep in mind that enzymes are high quality proteins that act as biological catalysts operating within and outside a cell, by initiating, speeding, 
slowing down or up even stopping chemical reactions.

\subsection{The Types of operators in a social organization}

We can differentiate analogue types of operators in the social organism, like we find them in enzymes in an individual organism. These are:

1) The feeding and caring operators

2) The energy supply operators

3) The repair and maintenance operators

4) The protection and defence operators

5) The education or training providers.

Naturally, the question arises in the context of the enzymes metaphor where will place the juridical and legal operators. In order to answer this question we need to get to a meta level and to broach the issues of evaluation and optimization of the functioning of the enzymes: the operators.

\subsection{The judicial operators}

When we look at and study the functioning of operators then we have to keep in mind the following distinctions:

1) First we need to keep an eye on the dyssocial operators. These are operators who carry out pseudo-support. Under the disguise of protection, restoration they commit instead destructtion of structures and bring about dysfunctionalities.

2) A second category of operators are operators who try to optimize their operational capacity, without regard to the harmony of the whole in which they optimize.

3) A third category of operators are those who optimize in function of an overall harmony of society in which they operate. They even strive for /pursue relative sub-optimization in function of a global optimization.

4) In the light of an evaluation of operators it could be interesting to examine to what extent inequality in appreciation and/or reward by operators could play a role as a epiphenomenon or as a motivator or demotivator of the intensity and quality of the activity and performance of an operator.
In this context, where can we situate the legal / justice operators? Are they the meta-operators who are stimulating and directing the other operators in the community up to a higher, greater harmony...! Legal / justice operators are and must be operators who support and guide other operators in conflict resolution to reach a larger and much higher level of social harmony.

8.5 Destructive developments due to some defence mechanism of the social / judicial system or the proteolytic or protective enzymes and their potential as a metaphor for the judicial derailments.

We know that in some circumstances enzymes can easily degenerate into forces that cause autoimmune reactions and become very harmful for the own organism. For example, we know that we should have the right acidity level in the body as an absolute condition to guarantee the normal running of the biochemical processes. For example, food digestive enzymes are for a proper functioning also dependent on a good $\mathrm{pH}$ balance in the stomach and intestinal tract. The stomach needs an acidic $(<\mathrm{pH} 7)$ environment while the small intestine just needs a basic (> pH 7) environment. The colon in turn requires a slightly acidic environment... In addition, we have that sugar kills enzymes. Eating refined sugars weakens the immune system after only 20 minutes. It inhibits the production of white blood cells (T-cells) ... But all is even much more complex. Dr. Paul Kouchakoff (Institute of Clinical Chemistry Lausanne) states that the performance of the enzymes is also influenced by what we eat: "After a 'normal' meal cooked at high temperature, which consists of a mixture of denatured proteins, carbohydrates with extra refined sugars and fats, an immune system response will develop in the body. This is what is called in difficult words 'digestive leukocytosis' process. This is a phenomenon that emerges when we eat cooked food. As our primitive blueprint actually is not aware of the change of the molecular structure of cooked food, an increase of the number of white blood cells emerges. 
Not only the number of white blood cells will increase, but also the correlation between the white blood cells will change. They are found in large numbers in the blood as if an acute poisoning is taking place. When we eat strongly heated foods, our body does not recognize certain parts of the cooked food and as a response the immune system will create extra white blood cells. When heating food, not the quantity, but the kind of food is decisive for the change in the blood composition. Warming up normal drinkable water for five minutes or half an hour to warm up to $87^{\circ} \mathrm{C}$ causes no changes, but water heated above $88^{\circ} \mathrm{C}$ does. That is the critical temperature. This reaction happens also when heating food in the microwave. The lowest temperature lies with water $87^{\circ} \mathrm{C}$, then milk $88^{\circ} \mathrm{C}$, cereals, tomatoes, cabbage, banana $89^{\circ} \mathrm{C}$, pears and meat $90^{\circ} \mathrm{C}$, butter $91^{\circ} \mathrm{C}$, apples and oranges $92^{\circ} \mathrm{C}$, potatoes $93^{\circ} \mathrm{C}$, carrots, raspberries and figs $97^{\circ} \mathrm{C}$. However, if we eat raw food before and also between our cooked meals, the phenomenon will not occur. That means that we reduce or even eliminate the poisoning. Eating unprocessed raw foodstuffs are recognized as "friendly and not hostile" and therefore causes no reaction in the blood. So our only protection against this reaction is the consumption of natural raw food together with the meals and chewing well. (Muylle: 12)".

Independently from the degree of accuracy of higher analysis and presentation by Paul Kouchanoff, we can notice that we have something analogous with the proteolytic or their equivalent social legal operators. In some environments, they may degenerate into auto-immune or social destructive processes. Some examples?

At an individual, enzymatic level, we see examples of food cooked at high temperatures, etc. Cooking food with additions of denatured proteins and refined sugars gives the important advantage that much more food is available to the individual, is preserved better and longer and that it can be produced and distributed cheaper in higher amounts. All these advantages, however, have the major disadvantage of putting in motion the proteolytic defense mechanisms excessively. The important side-phenomenon is a significant increase in auto-immune diseases, and a significant weakening of the individual organism.

Do we have at a social level, by stimulation and growth of judicial actors, analogous problems with hazards for the autoimmunity threats to social order and organization? We can think here of the immense growth and strengthening of the information and knowledge dissemination accompanied by an astronomical growth of the information and knowledge control around in society and even over the whole world. Like cooking with its related food improvement ingredients, is in the first instance a major benefit for the food supply to the individual, we can say the same for the rapid enormous dissemination of information and control over the entire world. Via satellites, drones and penetration of electronic networks, we see that at any time, day and night, the slightest movement and communication, exchange of signals of each individual can be and is controlled, also including the statements and actions carried out outside the networks. This at first sight is a very important enrichment. It generates de facto however the introduction of immeasurably second, third etc. level of legal operators following everything and everywhere. The proteolytic explosion that we find in the individual organism, we retrieve very clearly reflected in society. The greater the proteolytic legal actors explosion, the greater also the dangers to autoimmunity. Orwell, Huxley, and so many others have already pointed out the dangers in this regard.

We are now also seeing the negative impact this has on the limitation of creativity, innovation, diversity and flexibility, favoring stimulating brainwashing, stigmatization and depersonalization. Increased and excessive control, repression and oppression is an inevitable consequence of this tremendous growth. The so-called social networks play in this process of control, repressive brainwashing and depersonalization an 
enormous role. Such an important role that we should explicitly consider how should the legal framework be optimized to counter this exponential increase of control, depersonalization, brainwashing, destruction of creativity, flexibility, innovation, etc.

In this context we also want to refer to the knowledge control over e.g. prisoners with the expansion and extension through digital control, taking a huge expansion in size and efficiency of depersonalization, stigmatization, brainwashing... This "depersonalization" happens (1) by treating the individual as a number, whereby (2) each initiative is a priori excluded (again via a delaying time-consuming procedure), (3) organized structural inactivity (activation is only possible through third-party initiative), (4) temptation to medical sedation as the only (?) tolerated, accepted means in order to break through the structural inactivity and finally (5) absence of privacy self in the treatment of the personal dossier. Since the prisons mainly concern specific social groups, the social inequality is enlarged further bringing with it an increasing risk of inevitable social wild uncontrolled outbursts of social blind violence. Every increasing repression and growth through proteolytic repression actors, including the judicial actors, will inevitably cause increasing mindless violence and destruction: chaos. This is again diametrically opposed to the aims of app-lied scientific legal system and judiciary.

A tragic illustration of it, we see in the Middle East. The intensive sophisticated controls and in-

\section{REFERENCES}

Hintikka, J. \& Vandamme, F. (1985). Logic of discovery and logic of discourse. New York \& London, Plenum Press. Gent, C\&C.

Rousseaux, M., Wang, L. \& Vandamme, F. (2013). Het leeractieteam Cupie-Do, Leermoeheid in een holistisch perspectief. Gent, C\&C.

Vandamme, F. (2015). "A new Pedagogical Approach in Law Teaching". Scientia Paedagogica Experimentalis, Vol. 51. terventions by international proteolytic legal and military forces have created chaos, expanding through the flow of millions of refugees to Europe. This may result there too in total chaos.

\section{Conclusion}

In the light of the analyses of Bostjan M. Zupancic in, inter alia, "The Crown and the Criminal" on the one hand and the prospects of an applied scientific justice, we want to draw the following conclusions.

1) Applied scientific Justice is a possibility.

2) Like all scientific research and approach, applied scientific justice is dynamic. It is and should continuously be changed and adapted to meet the new frictions, social challenges, changes, threats, technical capabilities, social, economic opportunities and needs and the changes in scientific knowledge and technologies.

3) The core of applied scientific Justice is applied scientific conflict resolution. Such techniques are not only, like in individual and social conflicts, dynamic developments by themselves. The harmony perspectives encompassing the conflict resolutions are as much in dynamic evolution.

4) Moreover the individual and social harmony models orienting/ directing the conflict resolution perspectives, need to be maximally pluralistic and need to be especially explicitly elaborated, described, evaluated and validated in an applied scientific way by and with all parties.

Vanden Wijngaert, C. (2004). Strafrecht, strafprocesrecht \& Internationaal Strafrecht. Antwerpen, MAKLU.

Zupancic, B. (1997). "The Crown and the Criminal: Towards the General Principles of Criminal Procedure". European Review of Public Law, Vol.9, pp. 11-39.

Zupancic, B. (2007). Essays on Human Rights. The Owl of Minerva. Utrecht, Eleven International Publishing. 